http://jmscr.igmpublication.org/home/ ISSN (e)-2347-176x ISSN (p) 2455-0450 crossref DOI: https://dx.doi.org/10.18535/jmscr/v7i7.122

Journal Of Medical Science And Clinical Research

\title{
The blood glucose lowering effect of ethanolic extract of Emblica officinalis fruit in alloxan induced hyperglycaemic rats
}

\author{
Authors \\ Dr Zubaida Kha ${ }^{1}$, Ferdous Ara ${ }^{2}$, Onayza Yasmeen ${ }^{3}$, Israt Jahan ${ }^{4}$, Sharmin Nahar $^{5}$, \\ Sheikh Nazrul Islam6 \\ ${ }^{1}$ Medical Officer, Department of Pharmacology, Sir Salimullah Medical College and Mitford Hospital, \\ Dhaka \\ ${ }^{2}$ Professor, Department of Pharmacology, Delta Medical College and Hospital, Dhaka \\ ${ }^{3}$ Assistant Professor, Department of Pharmacology, Sir Salimullah Medical College and Mitford Hospital, \\ Dhaka \\ ${ }^{4}$ Assistant Professor, Department of Pharmacology, MH Samorita Hospital and Medical \\ College, Dhaka \\ ${ }^{5}$ Lecturer, Department of Pharmacology, Sir Salimullah Medical College and Mitford Hospital, Dhaka \\ ${ }^{6}$ Professor, Institute of Nutrition and Food Science, University of Dhaka, Dhaka
}

\begin{abstract}
Objective: in this study our main goal is to evaluate effect of $500 \mathrm{mg} / \mathrm{kg} \mathrm{b.w}$ ethanolic extract of Emblica officinalis in alloxan induced hyperglycaemic rats\& compare with the anti-diabetic drug Glibenclamide in lowering blood glucose level.

Method: this experimental type of study was conducted at Department of Pharmacology and Therapeutics of Sir Salimullah Medical College in collaboration with Institute of Nutrition \& Food Science (INFS) and Department of Pharmaceutical Chemistry of the University of Dhaka from January 2013 to December 2013 where 24 healthy Swiss Albino rats were tested during the study.Data was processed and analyzed.

Result: during the study in normal control group (Group A), the blood glucose levels (mean \pm SD) was 5.18 $\pm 0.14 \mathrm{mmol} / \mathrm{L}$ where as the serum glucose concentration in Alloxan treated group (Group B) was $12.35 \pm$ $0.42 \mathrm{mmol} / \mathrm{L}$. Also, the mean $\pm S D$ of serum glucose concentration in ethanolic extract group $C$ was $7.7 \pm$ $0.18 \mathrm{~m} \mathrm{~mol} / \mathrm{L}$ and in Glibenclamide treated group (group D) was $6.4 \pm 0.30 \mathrm{~m} . \mathrm{mol} / \mathrm{L}$.

Conclusion: from many examination, we can suggest that, the glucose lowering effect of 500mg doses of ethanolic extracts of E.officinalisis almost near effective to that of glibenclamide. So, ethanolic extract of Emblica officinalis may offer an alternate treatment for type II diabetes and its complications.

Keyword: Diabetes mellitus, ethanolic extract, Emblica officinalis.
\end{abstract}

\section{Introduction}

Diabetes mellitus is a clinical syndrome characterized by hyperglycaemia caused by absolute or relative deficiency of insulin. Lack of insulin affects the metabolism of carbohydrate, protein and fat, and can cause significant disturbance of water and electrolyte homeostasis. Death may result from acute metabolic decompensation. Long standing metabolic derangement is associated with functional and structural changes in many organs, particularly those of the vascular system, which lead to the 
clinical complications of diabetes. These characteristically affect the eye, the kidney and the nervous system.

The two main types of diabetes are called, type 1 and type 2 diabetes. In type 1 diabetes there is no insulin or not enough of it. In type 2 diabetes, there is generally enough insulin but the cells upon it should act are not normally sensitive to its action. $^{[1][2][3]}$

Diabetes mellitus is recognized by a triad of classical symptoms of polyuria (increased frequency of urination due to osmotic diuresis), polydipsia (increased thirst due to dehydration) \& polyphagia (increased appetite due to deprivation of cells from glucose).These symptoms are the consequences of hyperglycaemia in a diabetic person. ${ }^{[4]}$

Diabetes is diagnosed and monitored by blood glucose estimation, oral glucose tolerance test and level of glycosylated haemoglobin (HbA1C). According to WHO diagnostic criteria of 2006, a person is stated as diabetic when fasting blood sugar level is $>7.0 \mathrm{~m} \mathrm{~mol} / 1$ and 2 hours after meal, it is $>11.1 \mathrm{mmol} / \mathrm{l}$. HbAlc can be used as a diagnostic test for diabetes providing that stringent quality assurance tests are in place and assays are standardized to criteria aligned to the international reference values and there are no conditions present which preclude its accurate measurement. HbAlc of $6.5 \%$ is recommended as the cut point for diagnosis. A value of less than $6.5 \%$ does not exclude diabetes diagnosed using glucose tests. ${ }^{[5]}$

Bangladesh is full of medicinal plants, which are used by the people for the treatment of various diseases even at this modern era. There are various medicinal plants in the world, which are the potential sources of the drugs. Traditionally various plants are being used to treat diabetic patients.

The conventional anti-diabetic drugs available in the market have several common adverse effects $\&$ they also pose a financial burden to many diabetic patients. On the contrary, the herbal alternatives may be a better option due to lack of such adverse effects \& are a cheaper choice of treatment. Some herbal products such as Bitter gourd (Mimordicachirantia), Garlic (Allium sativum), Ginger (Zingiber offmale), Kalijira (Niextractlasativd), Cmnamon (Cinnamon cassia) are now becoming popular due to their antidiabetic property. ${ }^{[6][7]}$

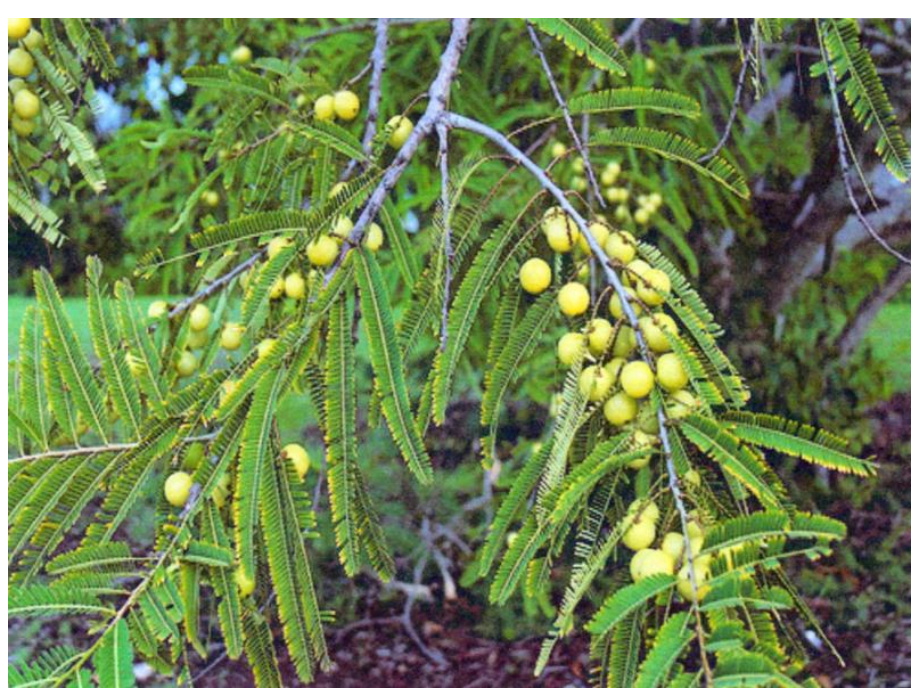

Figure-1: Tree of Emblica officinalis.

The this present study focus on our main objective is to evaluate medicinal efficiency of the effect of 500mg dose of ethanolic extract of Emblica officinalis with the anti-diabetic drug Glibenclamide in lowering blood glucose level.

\section{Objective}

\section{General Objective}

$>$ To assess medicinal efficiency of the effect of 500mg dose of ethanolic extract of Emblica officinalis with the antidiabetic drug Glibenclamide in lowering blood glucose level.

\section{Specific Objective}

$>$ To detect the outcome of glibenclamide on fasting blood glucose level of alloxan induced hyperglycaemic rats rat.

$>$ To evaluate ethanolic extract of Emblica officinalis on fasting blood glucose level of alloxan induced hyperglycaemic rats. 
Methodology

Type of study $\quad$ Experimental type of study

Place of study Department of Pharmacology and Therapeutics of Sir Salimullah Medical College in collaboration with Institute of Nutrition \& Food Science (INFS) and Department of Pharmaceutical Chemistry of the University of Dhaka

\begin{tabular}{l|l}
\hline Study period & January 2013 to December 2013 \\
\hline Study & 24 healthy Swiss Albino rats were \\
population & purchased from the animal house of \\
& Jahangirnagar University, Savar \\
& Dhaka. \\
\hline
\end{tabular}

\begin{tabular}{l|l}
\hline $\begin{array}{l}\text { Sampling } \\
\text { technique }\end{array}$ & Purposive
\end{tabular}

\section{Method}

The experiment was carried out in two parts; Experiment -I and Experiment -II. A total number of 24 healthy Swiss Albino rats were purchased from the animal house of Jahangirnagar University, Savar Dhaka. The age of the rat was between 8-10 weeks of both sex and weighing between 100-120 gms. 500gm crushed amla was taken into a conical flask of 5 litre capacity and socked in $500 \mathrm{ml}$ of $80 \%$ ethanol, shaking and mixed., then filtered with filtered paper. The ethanolic filtrate was condensed by the rotatory vacum evaporator at $40^{\circ} \mathrm{C}$ and at 60-70 revolution per minute, then extract was prepared for use \& stored in refrigerator. It was comprised of 24 rats divided as:

Group A (Normal control group): In this group rats were given standard rat feed \& water for28days.fasting blood glucose level was estimated on day $1 \& 29^{\text {th }}$ day of the experiment.

Group B (Diabetic control group): These groups of rats were administered alloxan $120 \mathrm{mg} / \mathrm{kg}$ b.w. on first day of the experiment. After intra peritoneal injection rat were given standard food and water. Fasting blood glucose level was estimated on day 1 (before alloxan), on day 4 (after alloxan to confirm induction of diabetes mellitus),

Group C (Experimental group): These groups of rats were administered alloxan $120 \mathrm{mg} / \mathrm{kg}$ b.w. on first day of the experiment. After intra peritoneal injection rat were given standard food and water. Fasting blood glucose level was estimated on day 1 (before alloxan), on day 4 (after alloxan to confirm induction of diabetes mellitus) means of micropipette along with standard food and water for 28 days. C groups were administered ethanoicl extract of Emblica officinalis $500 \mathrm{mg} / \mathrm{kg}$ b.w orally by means of micropipette along with standard food and water for 28 days

Group D (Anti diabetic drug group): This group was given alloxan $120 \mathrm{mg} / \mathrm{kg}$ b.w. intraperitoneally on day 1. After alloxan injection rats were given standard food. From day 4 onwards, Glibenclamide orally given at a dose of $5 \mathrm{mg} / \mathrm{kg}$ b.w.

\section{Statistical Analysis}

The results are given as Mean \pm SD for the seven independently performed experiments. Unpaired student's " $t$ " test was used to see the level of significance. $\mathrm{P}$ value $<0.05$ was considered statistically significant. ANOVA test was used to see the level of significance among comparison more than two groups, $\mathrm{p}$ value $<0.05$ was considered statistically significant.

\section{Result}

In table-1 shows effect of alloxan on fasting blood glucose level on rat where in normal control group (Group A), the blood glucose levels (mean \pm SD) was $5.18 \pm 0.14 \mathrm{mmol} / \mathrm{L}$ where as the serum glucose concentration in Alloxan treated group (Group B) was $12.35 \pm 0.42 \mathrm{mmol} / \mathrm{L}$.

The mean rise of serum glucose concentration in group B compared to that of group A was done by unpaired student's t test \& the result was highly significant $(\mathrm{p}<0.001)$. So, Alloxan significantly increase blood glucose level. The following table is given below in detail: 
Table 1: Effect of Alloxan on fasting blood glucose level on rat:

\begin{tabular}{|c|c|c|c|}
\hline Group & $\begin{array}{l}\text { No: of } \\
\text { Rats }\end{array}$ & \multirow{2}{*}{$\begin{array}{l}\text { Fasting Blood } \\
\text { Glucose } \\
\text { (m mol/l) (Mean } \pm \\
\text { SD) On } 29^{\text {th }} \text { day of } \\
\text { experiment }\end{array}$} & p-value \\
\hline & & & \multirow[t]{3}{*}{$\begin{array}{l}\mathrm{p}<0.001 \\
\text { A Vs B }\end{array}$} \\
\hline $\mathbf{A}$ & 6 & $5.18 \pm 0.14$ & \\
\hline B & 6 & $12.35 \pm 0.42$ & \\
\hline
\end{tabular}

In figure-2 shows outcome of alloxan on fasting blood glucose level on rat where in normal control group (Group A), the blood glucose levels (mean $\pm \mathrm{SD}$ ) was $5.18 \pm 0.14 \mathrm{mmol} / \mathrm{L}$ where as the serum glucose concentration in Alloxan treated group (Group B) was $12.35 \pm 0.42 \mathrm{mmol} / \mathrm{L}$. The following figure is given below in detail:

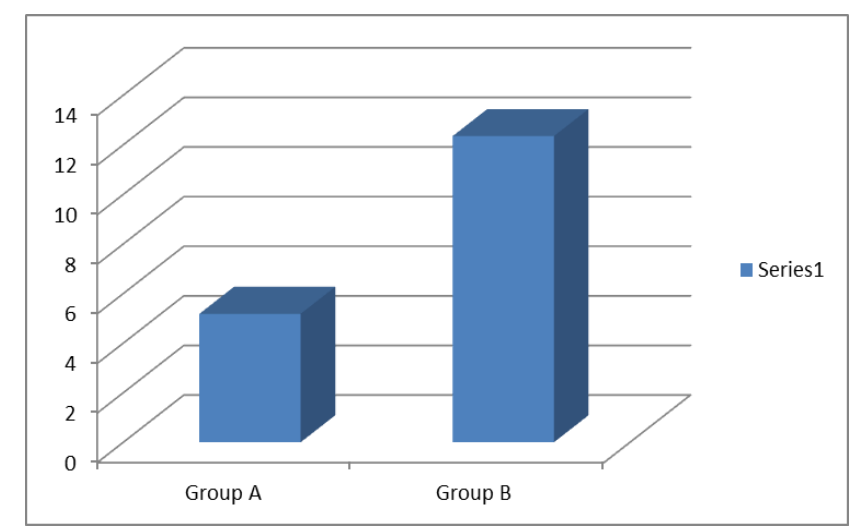

Figure 2: Outcome of alloxan on fasting blood glucose level on rat

In table-2 shows effect of ethanolic extract of Emblica offlcinalis on fasting blood glucose level of alloxan induced hyperglycaemic rats where the mean \pm SD of serum glucose concentration in (Ethanolic Emblica officinalis extract $500 \mathrm{mg} / \mathrm{kg}$ b.w treated) group $\mathrm{C}$, was $7.7 \pm 0.18 \mathrm{~m}$. mol/ $\mathrm{L}$, and in group $\mathrm{B}$ (treated with alloxan) was $12.35 \pm$ $0.42 \mathrm{mmol} / \mathrm{L}$. The mean reduction of serum glucose concentration in groupC compare to that of group ' B ' was done by unpaired student' t test $\&$ the result was statistically significant ( $\mathrm{p}<$ 0.001) .So the ethanolic extracts of E.officinais produce significantiy decreased blood glucose level. The following table is given below in detail:
Table - 2: Effect of ethanolic extract of Emblica offlcinalis on fasting blood glucose level of alloxan induced hyperglycaemic rats.

\begin{tabular}{|c|c|c|c|}
\hline \multirow[t]{2}{*}{ Group } & \multirow{2}{*}{$\begin{array}{l}\text { No: of } \\
\text { Rats }\end{array}$} & \multirow{2}{*}{$\begin{array}{c}\text { Fasting Blood Glucose } \\
(\mathrm{m} \text { mol} / 1)(\text { Mean } \pm \text { SD }) \\
\text { On } \\
29^{\text {th }} \text { day of experiment }\end{array}$} & p-value \\
\hline & & & \multirow[t]{3}{*}{$\begin{array}{c}\mathrm{p}<0.001 \\
\mathrm{~B} \text { Vs C }\end{array}$} \\
\hline B & 6 & $12.35 \pm 0.42$ & \\
\hline $\mathrm{C}$ & 6 & $7.7 \pm 0.18$ & \\
\hline
\end{tabular}

In figure-3 shows outcome of ethanolic extract of Emblica offlcinalis on fasting blood glucose level of alloxan induced hyperglycaemic rats where the mean \pm SD of serum glucose concentration in (Ethanolic Emblica officinalis extract $500 \mathrm{mg} / \mathrm{kg}$ b.w treated) group $\mathrm{C}$, was $7.7 \pm 0.18 \mathrm{~m} . \mathrm{mol} / \mathrm{L}$, and in group $\mathrm{B}$ (treated with alloxan) was $12.35 \pm$ $0.42 \mathrm{mmol} / \mathrm{L}$. The following figure is given below in detail:

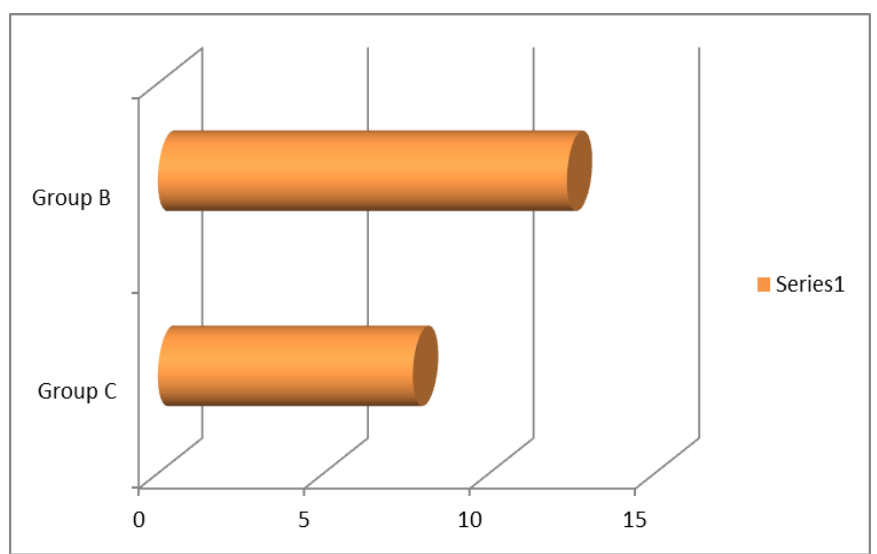

Figure-3: Outcome of ethanolic extract of Emblica offlcinalis on fasting blood glucose level of alloxan induced hyperglycaemic rats.

In table-3 shows effect of ethanolic extracts of Emblica officinalis \& Glibenclamide on fasting blood glucose level of alloxan induced hyperglycaemic rats where the mean \pm SD of serum glucose concentration in ethanolic extract group $\mathrm{C}$ was $7.7 \pm 0.18 \mathrm{~m} \mathrm{~mol} / \mathrm{L}$ and in Glibenclamide treated group (group D) was 6.4 \pm $0.30 \mathrm{~m}$. mol/L. Comparison of fasting blood glucose level of group $\mathrm{C}$ with that of group D was done by unpaired student's t test $\&$ the result was not statistically significant. The following table is given below in detail: 
Table - 3: Effect of ethanolic extracts of Emblica officinalis \& Glibenclamide on fasting blood glucose level of alloxan induced hyperglycaemic rats

\begin{tabular}{|c|c|c|c|}
\hline \multirow[t]{2}{*}{ Group } & No: & Fasting Blood Glucose & p-value \\
\hline & $\begin{array}{c}\text { of } \\
\text { Rats }\end{array}$ & $\begin{array}{c}(\mathrm{m} \mathrm{mol} / 1)(\text { Mean } \pm \mathrm{SD}) \\
\text { On } 29^{\text {th }} \text { day of } \\
\text { experiment }\end{array}$ & \multirow[t]{3}{*}{$\begin{array}{l}\mathrm{p}>0.05 \\
\mathrm{CV} \text { s D }\end{array}$} \\
\hline $\mathrm{D}$ & 6 & $6.40 \pm 0.30$ & \\
\hline $\mathrm{C}$ & 6 & $7.70 \pm 0.18$ & \\
\hline
\end{tabular}

In figure-4 shows result of ethanolic extracts of Emblica officinalis \& Glibenclamide on fasting blood glucose level of alloxan induced hyperglycaemic rats where the mean \pm SD of serum glucose concentration in ethanolic extract group $\mathrm{C}$ was $7.7 \pm 0.18 \mathrm{~m} \mathrm{~mol} / \mathrm{L}$ and in

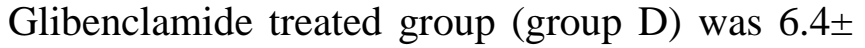
$0.30 \mathrm{~m}$. mol/L. The following figure is given below in detail:

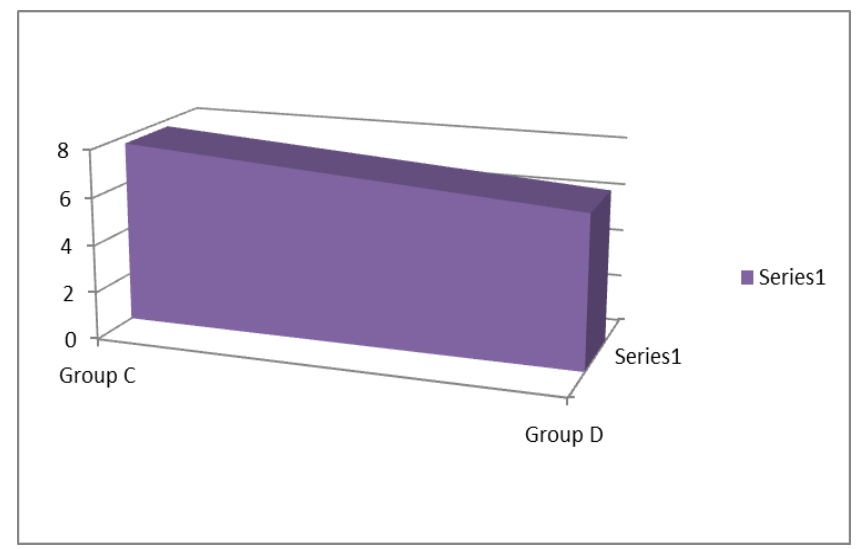

Figure 4: Result of ethanolic extracts of Emblica officinalis \& Glibenclamide on fasting blood glucose level of alloxan induced hyperglycaemic rats.

\section{Discussion}

Many anti-diabetic medications have significant side effects that are not popular with patients, have limited effectiveness, or lack evidence of impacting the course of the disease. An increasing interest in herbal and complementary medicine has led to a search for effective natural therapies that have significant effects on blood sugar level (Diabetes Action Research and Education Foundation, 2010). Herbal treatment can be a safe and cost-effective way to combat diabetes.
The present research work has been undertaken based upon the above mentioned expectation. For this purpose the present study was carried out to evaluate the effect of ethanolic extract of Emblica officinalis on blood glucose level of experimentally induced hyperglycaemic rat. Blood glucose lowering effect of Emblica officinalis was tested on non-diabetic and experimentally induced hyperglycaemic rat with duration of 28 days. The glucose lowering effect of Emblica officinalis was compared with a standard oral anti diabetic drug, Glibenclamide.

Effect of ethanolic extracts of E.officinalis was observed in alloxan induced hyperglycaemic rats \& compared with a standard drug Glibenclamide. Reduction in the mean blood glucose level was observed in the experimental hyperglycaemic group when treated with ethanolic extract of E.officinalis500mg/kg b.w., (Group-C), \& compared with Glibenclamide $5 \mathrm{mg} / \mathrm{kg}$ bw (Group-D) after 28 days. Administration of a single dose of intrapritoneal Alloxan monohydrate was given at $120 \mathrm{mg} / \mathrm{kg}$ b.w. initially, to induce diabetes in these experimental groups.

It may then be suggested that, the glucose lowering effect of ethanolic extracts of E.officinalis is almost near effective to that of glibenclamide.

One study reported in their study that, when they treated diabetic rats with PFEet and glibenclamide displayed a significant decrease in blood glucose with significant increase in plasma insulin level as compared to diabetic control rats. The possible machinery by which PFEet bring about itsantihyperglycemic action may be by increasing the pancreatic secretion of insulin from remnant Bcells, which was clearly evidenced by the increased level of insulin in diabetic treated rats.

A numeral of other plants has been described to exert hypoglycemic activity throughinsulin release-stimulatory effects. The effect created by the extract was compared with standard drug, glibenclamide. Phytochemical analysis of the fruit exposed the presence of tannins, flavonoids, alkaloids, terpenoids, carbohydrates and proteins. 
These compounds are dominant antioxidants to scavenge the free radicals induced by hyperglycemia. ${ }^{[8][9]}$

\section{Conclusion}

From our experiment we can conclude that blood glucose lowering effect of different extracts of E.officinalis were compared to that of glibenclamide \& the changes were not significant ( $>0.05)$. It may then be suggested that, the glucose lowering effect of ethanolic extracts of $E$. officinalis is almost near effective to that of glibenclamide. So, ethanolic extract of Emblica officinalis may offer an alternate treatment for type II diabetes and its complications. Further study is needed for better result in near future.

\section{Reference}

1. Wild, S., Roglic, G., Green, A. Sicree, R., King, H., (2004). 'Global prevalence of Diabetes: Estimates for the year 2000 \& projections for 2030'. Diabetes Care, 27, pp. $1047-1053$

2. Rahim, M.A., Hussain, A., Khan, A.K.A., Sayeed, M.A., All, S.M.K., Vaaler, S., (2007). 'Rising prevalence of type 2 diabetes in rural Bangladesh: A population based study'. Diabetes Research \& Clinical practice, 77(2), pp. 300-305

3. Rajasekaran, S., Ravi, K., Sivagnanam, K. \& Subramanian, S., (2006). 'Beneficial effects of Aloevera gel extract on lipid profile status in rats with streptozotocin diabetes'. Clinical \& experimental pharmacology \& physiology, 33, pp. 232237.

4. Nicholas, A., Boon, N.R., Colledge, B.R., Walker, (2004). Davidson's Principles \& Practice of Medicine, 22 ${ }^{\text {nd }}$ Edition, pp. 812-815 available at http://secureecsd.elsevier.com/uk/files/med/22kevpoint s abouthe22edition.pdf
5. Chopra, R.N, Chopra, I.C., Handa, L.L. \& Kapur, L.D, (1982). 'Chopra's indigenous drugs of India $2^{\text {nd }}$ edition'. Academic publishers, pp. 605,673,682,688

6. Daisy, P.H.I., Averal \& Modilal, R.D., (2004). 'Curative properties of phyllanthus extracts in alloxan induced diabetic rats'. $J$. Trop. Med. plants, 5, pp.21-27

7. Halluwell, B., Gullerdge, J.M.C. \& Cross, E.S., (1992). 'Free radicals \& human disease: Where are we now'?,J. Lab. Clin. Med, 119, pp.598-620

8. Krishnaveni, Mani, Sankaran Mirunalini, Kandan Karthishwaran, and Ganesan Dhamodharan. "Antidiabetic and antihyperlipidemic properties of Phyllanthus emblicaLinn. (Euphorbiaceae) on streptozotocin induced diabetic rats." Pak J Nutr 9, no. 1 (2010): 43-51.

9. Twaij, H.A.A. and A.A. Al-Badr, 1988. Hypoglycemic activity of Artemisiaherba alba . J. Ethnopharmacol.,24: 123-126. 